\title{
Randomness, Causation, and Divine Responsibility
}

\author{
Scott A. Davison
}

What does it mean to say that someone is responsible for something? It turns out that the concept of responsibility is both vague and ambiguous. Let us say that someone is casually responsible for something $\mathrm{E}$ in virtue of actively contributing causally to E's production. ${ }^{1}$ Being causally responsible for something $\mathrm{E}$ is not enough, all by itself, for being morally responsible for E, where moral responsibility includes also the possibility of the appropriate application of the retrospective, reactive attitudes of praise or blame. ${ }^{2}$ But being causally responsible does seem to be necessary for being morally responsible. ${ }^{3}$

\footnotetext{
${ }^{1}$ Could one also be causally responsible for the occurrence of something E simply because one failed to prevent it? This is an interesting and complicated question; I do not want to enter the dispute about it here, so I will simply set it aside. (For a powerful and detailed discussion of the power of causal absences, see Goldschmidt 2016.)

${ }^{2}$ Being morally responsible for something does not imply that one deserves praise or blame for it, though — one might be morally responsible for something that is neutral, in such a way that neither praise nor blame is appropriate.

${ }^{3}$ See Fischer and Ravizza 1998, chapter 1.
}

S. A. Davison $(\bowtie)$

Morehead State University, Morehead, KY, USA

e-mail: s.davison@moreheadstate.edu

(C) The Author(s) 2022

K. J. Clark, J. Koperski (eds.), Abrahamic Reflections on

Randomness and Providence, https://doi.org/10.1007/978-3-030-75797-7_17 
What else is necessary for being morally responsible? Although there is sharp disagreement about this, ${ }^{4}$ it seems to me that moral responsibility requires the capacity for foresight, the capacity for causal contribution, and the capacity for intentional action directed at a particular outcome. But I will not argue for these claims here, and as far as I can tell, nothing I say in this chapter assumes that they are correct. It is important to note that one could satisfy all of the criteria for being morally responsible for something that is neutral, so that one does not deserve praise or blame for it - rather than create a new category of responsibility to cover this kind of case, we should just keep in mind its possibility. ${ }^{5}$

Consider the following thesis:

Divine Moral Responsibility: God is morally responsible to some substantial degree for the occurrence of every contingent event.

There seems to be strong support for Divine Moral Responsibility from the Jewish, Christian, and Islamic traditions (e.g., see Freddoso 1988). In virtue of creating and sustaining the contingent universe, God contributes causally to every contingent event. Furthermore, God has the maximum capacity for foresight possible, and the greatest possible capacity for intentional action directed at particular outcomes. ${ }^{6}$

But suppose that there are ontologically random events in the universe, events which have no sufficient cause and could have turned out differently in some respect, given the same initial conditions and laws of nature. Would the existence of such random events count against Divine Moral Responsibility? To explore this question, I will begin with a muchdiscussed approach to the problem of evil and God's responsibility for free creaturely actions before turning to questions about shared moral responsibility.

${ }^{4} \mathrm{~A}$ great deal has been written about the claim that libertarian freedom is necessary for moral responsibility; see Frankfurt 1969, Nagel 1976, Adams 1985, Fischer and Ravizza 1998, and Morriston 2000 for the tip of the proverbial iceberg. Libertarian accounts of free action have their defenders (see, for instance, Van Inwagen 1983, Kane 1985, O'Connor 2000, and Clarke 2003), but they are not as popular today as their compatibilist rivals. I will not try to resolve this dispute here.

${ }^{5}$ For an interesting argument for the conclusion that God's unsurpassable goodness implies that God does not deserve praise or thanks, see Howard-Snyder 2008.

${ }^{6}$ This might lead us to think that for God, unlike for human beings, there is no such thing as casual contribution without moral responsibility. 


\subsection{Augustinian Approaches to Evil}

How could a perfectly good creator make a less than perfectly good world? Historically, the most popular approach to answering this question involves trying to blame the imperfections of the created world on created agents, rather than the creator, where such created agents are viewed as introducing randomness into the world in a way that provides some casual distance between God and evil. This strategy typically assumes that if one person is fully morally responsible for something, then nobody else is morally responsible to any degree for that same thing. In this section, I will explore the role that this assumption plays in typical Augustinian approaches to the problem of evil, and then explain in the next section why it is false.

Contemporary interest in the problem of evil can be traced to rigorous formulations of the problem generated by J. L. Mackie (1955) and H. J. McCloskey (1960). Their articles led to influential responses from John Hick (1966) and Alvin Plantinga (1974a, b), among others. In his survey of historical approaches to the problem, Hick distinguished between two groups of theodicies, the Augustinian and Irenaean, where the former explains evil as an accidental by-product of the free choices of creatures, and the latter explains it as necessary for moral development ("soul-making"). ${ }^{7}$ Hick himself defended an Irenaean approach, whereas Plantinga developed a highly technical formulation of the Augustinian approach called the Free Will Defense. Plantinga's Augustinian approach has received the lion's share of attention in the literature, and I will return to it later. But it will be helpful to begin with St. Augustine himself in order to explain in more general terms how assumptions about causality and moral responsibility function in an Augustinian approach. ${ }^{8}$

\footnotetext{
${ }^{7}$ St. Augustine's theodicy is not the first one to be based explicitly on human freedom, though - that honor might belong to the author of the Biblical account in Genesis 3. Or it might belong to the great Stoic Cleanthes of Assos (c.331-232 BCE; see the discussion of Stoic responses to the problem of evil in Jordan 1987, 200-5); a version of this strategy can also be found in Plato's Timeaus $(42 \mathrm{~d}-\mathrm{e})$. There is more to St. Augustine's position than the argument concerning freedom and moral responsibility that I explore here, but I will continue to use Hick's label ("Augustinian") because it has become commonplace in the literature on this question; for perhaps the most detailed classification and survey of possible responses to the problem of evil, see Tooley's essay in Plantinga and Tooley 2008.

${ }^{8} \mathrm{I}$ am not an expert in St. Augustine's thought and do not claim that my brief summary here sheds any new light on his views; instead, I will draw only upon one of his early work (On Free Choice of the Will), which seems to capture adequately the general outlines of what I am calling here an Augustinian approach.
} 
In trying to explain how "the goods pursued by sinners are in no way evil things, and neither is free will itself," St. Augustine says that

When the will clings to the common and unchangeable good, it attains the great and foremost goods for human beings. ... But when the will turns away from the unchangeable and common good toward its own private good, or toward external or inferior things, it sins. (St. Augustine 1993, 68)

This movement of the will, the turning away from a higher good to embrace a lower one, is the essence of evil, according to Augustine. ${ }^{9}$ Since this movement is "not coerced, but voluntary, it is justly and deservedly punished with misery" (Augustine 1993, 68). What is the cause of this movement of the will, one might ask? Augustine answers:

But perhaps you are going to ask what is the source of this movement by which the will turns away from the unchangeable good toward a changeable good. This movement is certainly evil, even though free will itself is to be counted among good things, since no one can live rightly without it. For if that movement, that turning away from the Lord God, is undoubtedly sin, surely we cannot say that God himself is the cause of sin. So that movement is not from God. (St. Augustine 1993, 69)

St. Augustine seems to argue here as follows:

1. If God were the cause of evil, then God would be morally responsible for evil.

2. God is not morally responsible for evil.

Therefore,

3. God is not the cause of evil.

Although there are questions (to which I shall return later) about what exactly it is saying, to defend premise 2, the Augustinian might offer the following argument:

\footnotetext{
${ }^{9}$ Here I am concerned only with what is often called moral evil, as opposed to natural evil (see Plantinga 1974a, 30). Plantinga claims that St. Augustine himself thought that all evil was moral evil, because he thought that all cases of apparently natural evil were caused by "Satan and his cohorts": see Plantinga 1974a, 58.
} 
4. If a created person $S$ performs an evil action A freely, then God does not cause S's performance of A.

5. If God does not cause created person S's performance of an evil action A, then God is not morally responsible to any degree for S's performance of $\mathrm{A}$.

Therefore,

6. If a created person $S$ performs an evil action A freely, then God is not morally responsible to any degree for S's performance of A.

There is something to be said in defense of each of these premises. First, premise 4 reflects the Augustinian's libertarian view of the nature of free action, according to which an action is free only if it is not determined. This view of freedom, which implies what I have called ontological randomness, seems essential to the Augustinian approach to the problem of evil. ${ }^{10}$ As Plantinga says, "Now God can create free creatures, but He can't cause or determine them to do only what is right. For if $\mathrm{He}$ does so, then they aren't significantly free after all; they do not do what is right freely" (Plantinga 1974a, 30). One of Plantinga's most vocal critics, J. L. Mackie, seems to agree:

[The Free Will Defense] alone allows the theist to admit that there are some real and unabsorbed evils, some items which the world would, from however broad and ultimate a perspective, be better without (so that this is not the best of all possible worlds), and yet at the same time to detach their occurrence from God, to show them as not having been chosen by God.. (Mackie 1982, 156)

Second, premise 5 is a clear consequence of the following general principle:

\footnotetext{
${ }^{10}$ For more on St. Augustine's libertarianism, see the preface to Augustine 1993, xi-xiv. Libertarian accounts of free action have their defenders (see, for instance, Van Inwagen 1983, Kane 1985, O'Connor 2000, and Clarke 2003), but they are not as popular today as their compatibilist rivals. A great deal has been written about the Augustinian claim that libertarian freedom is necessary for morality in general, or praise and blame in particular; see Frankfurt 1969, Nagel 1976, Adams 1985, Fischer and Ravizza 1998, and Morriston 2000 for the tip of the proverbial iceberg. I will not discuss here the plausibility of libertarian accounts of free action or the alleged connection between libertarian freedom and responsibility.
} 
7. A person $S$ is morally responsible for something $E$ to some degree only if $S$ causes $E$.

However, the inference from 4 and 5 to 6 is problematic. In order for 4 to be true, the word "cause" must be understood as "provide a causally sufficient condition," because God clearly provides many causally necessary conditions for creaturely free action (more on this later). To avoid equivocation, then, "cause" must be understood in the same way in 5 (and hence in 7). But in general, providing a causally sufficient condition for an event $\mathrm{E}$ is not necessary for being morally responsible for E. ${ }^{11}$ For example, "If two people pick up a heavy rock [together] and chuck it on a third person's head, both will be responsible for the consequent injury" (Zimmerman 1985b, 355). So 5 and 7 are not plausible if "cause" is understood in the way that is required for 4 to be true. Could the Augustinian argument be revised in order to accommodate this fact about causation and moral responsibility?

Here is the most natural and straightforward way to revise 7 in order to meet this objection:

8. A person $S$ is morally responsible to some degree for something $\mathrm{E}$ only if $\mathrm{S}$ contributes causally to the production of $\mathrm{E}$ to some degree.

From 8, one might infer 9:

9. If God does not contribute causally to any degree to a created person S's performance of an evil action A, then God is not morally responsible to any degree for S's performance of A.

These revisions yield the following version of the Augustinian argument:

10. If a created person $S$ performs an evil action A freely, then God does not contribute causally to any degree to S's performance of evil action A (replacing 4).

\footnotetext{
${ }^{11}$ Some will say that 5 is false for another reason: because it is possible to be responsible for something that one fails to prevent, even though one does not contribute causally to its occurrence. (Still others would say, to the contrary, that the failure to prevent something is itself a kind of causal contribution.) I do not want to enter this dispute here, so I will simply set it aside; for a powerful and detailed discussion of the power of causal omissions, see Goldschmidt 2016.
} 
9. If God does not contribute causally to any degree to a created person S's performance of an evil action A, then God is not morally responsible to any degree for S's performance of A (replacing 5).

\section{Therefore}

6. If a created person $S$ performs an evil action A freely, then God is not morally responsible to any degree for S's performance of A.

Before commenting on the strength of this argument, I should point out that throughout the chapter, I am talking about causation in the sense of efficient causation (not formal, final, or material causation, to use Aristotelian terminology). Even if God does not exist on the same ontological plane as creatures, as some people say, traditional theists hold that God is an efficient cause of the obtaining of various states of affairs in the world, whether or not God's causation involves other created agents as intermediaries.

Returning now to the argument: it is clearly valid, but according to traditional theism, the first premise (i.e., proposition 10) is false. This is because according to traditional theism, God creates, sustains, and cooperates with the action of every created cause in the world, including free human beings (see the discussion of this point in Freddoso 1988); so God must contribute causally to the performance of every creaturely action, even those evil human actions that are free in a libertarian sense. But since God's causal contribution is not sufficient, all by itself, for the performance of those evil actions, and God does not intend them per se, the Augustinian approach outlined earlier would insist that God is not to be blamed for them. ${ }^{12}$ As the sixteenth-century Spanish Jesuit theologian Luis de Molina says,

From what has been said we have it only that our morally evil actions are not attributed to God as to a positive cause who has an influence on them. This is in accord with the example of the workman who produces swords. For just as the deeds which are done by those who do not use the swords rightly are not imputed to the workman (for the swords are indifferent with respect

${ }^{12}$ I will return below to the question of the relationship between moral responsibility and blame. 
to good or bad use), but are instead imputed to the free choice of those who use the swords badly, so too, since God's general concurrence is indifferent with respect to good and evil actions, the evil actions should not be attributed to God, but should rather be attributed to those who abuse God's general concurrence in order to do evil. (Molina 1989)

In other words, since created persons freely determine for themselves whether their actions are good or evil, they are completely morally responsible for this, and therefore God is not. St. Augustine seems to agree:

There is nothing I feel so firmly and so intimately as that I have a will by which I am moved to enjoy something. If the will by which I choose or refuse things is not mine, then I don't know what I can call mine. So if I use my will to do something evil, whom can I hold responsible but myself? (St. Augustine 1993, 72)

Perhaps, then, the following argument captures better than the previous ones the Augustinian approach to the problem of evil:

11. If a created person $S$ performs an evil action $A$ freely, then $S$ is fully morally responsible for performing A.

12. If one person is fully morally responsible for something $\mathrm{E}$, then no other person is morally responsible to any degree for E.

Therefore,

6. If a created person $S$ performs an evil action A freely, then God is not morally responsible to any degree for S's performance of A.

This argument seems to capture the essence of the Augustinian approach. But is this argument sound, assuming that free creaturely action involves the kind of randomness described earlier? If so, then it seems that Divine Moral Responsibility is false, because God is not morally responsible to any degree for creaturely evil actions. And a parallel argument would seem to show that God is not morally responsible to any degree for any free creaturely actions at all, whether good or evil-but this would seem to be quite problematic, at least from the point of view of traditional theism. 


\subsection{Zimmerman on Shared Responsibility}

It seems to me that Michael J. Zimmerman has shown that premise 12 is false. ${ }^{13}$ In this section, I will present and extend his arguments for this conclusion. Along the way, I will also criticize his arguments for the view that degree of causal contribution is not a factor in determining degree of moral responsibility.

Zimmerman discusses possible cases of group action which are either oversupplied (i.e., "there is a greater supply of agents involved in the action than is in fact causally necessary for the outcome at issue") or standard (i.e., not oversupplied: see Zimmerman 1985a, 116). According to Zimmerman, group action involves more than one individual acting together in such a way that each one contributes causally to a single outcome. ${ }^{14}$ Consider the following case of standard group action, to which Zimmerman refers as case X:

Imagine a group of teenagers pushing a large boulder off a plateau, so that it rolls down a slope and wrecks a car at the bottom. Each of the teenagers intends to contribute to the damage to the car and freely participates in the enterprise, in the full knowledge that his contribution to the enterprise is required if the boulder is to be shifted and the car wrecked at all. (Zimmerman 1985a, 116)

Zimmerman argues that in this case, each of the teenagers involved is fully morally responsible for the damage to the car. His argument for this interesting conclusion involves an appeal to a slightly different case, $\mathrm{Y}$, which differs from case $\mathrm{X}$ in only one respect: in $\mathrm{Y}$, just one of the teenagers involved in case $\mathrm{X}$ is present (let's call him " $\mathrm{S}$ "), and this teenager wrecks the car all by himself. In this case, Zimmerman claims, "there would be no hesitation in ascribing to $S$ full (that is undiminished; not merely sole) responsibility for the damage" (116). In both cases, S's action is causally necessary but not causally sufficient by itself for the damage (since S's action requires the co-operation of other factors or agents in both cases, such as the boulder being able to be moved, the boulder and the car being

${ }^{13}$ Although other work on shared responsibility has been done since then, as far as I can tell, Zimmerman was the first to articulate this clearly, and his formulation of the question remains the standard formulation.

${ }^{14}$ Although this description does not imply that the members of the group share a common purpose or make a concerted effort: see Zimmerman 1985a, 115-6. 
properly positioned relative to one another, the force of gravity, etc.). More formally, here is Zimmerman's argument in detail:
(A) The only respect in which case $\mathrm{X}$ differs from case $\mathrm{Y}$ concerns the type of co-operation which $S$ receives in his endeavor.
(B) This respect provides no reason to ascribe a lesser degree of moral responsibility to $S$ in case $X$ than in case $Y$.
(C) If (A) and (B), then $S$ is just as morally responsible for the out- come in case $\mathrm{X}$ as in case $\mathrm{Y}$.
(D) In case $\mathrm{Y}, \mathrm{S}$ is fully morally responsible for the outcome.

So,

(E) In case $\mathrm{X}, \mathrm{S}$ is fully morally responsible for the outcome.

Therefore,

(F) In case $\mathrm{X}$, all participants in the action are fully morally responsible for the outcome (Zimmerman 1985a, 117).

I think that Zimmerman's main argument here is essentially right, although it seems to presuppose that degrees of moral responsibility do not depend upon degrees of causal contribution. This is especially evident in connection with premise (D). It is one thing to claim that someone acts without excuse, so that his or her moral responsibility is undiminished because of co-operating factors; it is another thing to claim that someone is fully morally responsible for something. Full moral responsibility would be responsibility to the highest degree possible, and degree of causal contribution does indeed seem to be relevant to determining this. ${ }^{15}$ Let me explain.

Consider Zimmerman's agent $S$, the teenager in case $Y$ who pushed the boulder down the slope and wrecked the car all by himself. Case Y must

\footnotetext{
${ }^{15}$ In personal correspondence, Zimmerman has explained that by "full" moral responsibility, he meant only undiminished-by-any-excuse moral responsibility and not moral responsibility to the highest possible degree, because he does not know how to make sense of the idea of such a maximal degree. As will become clear, it seems to me that $S$ would have the highest degree of moral responsibility for $\mathrm{E}$ just in case $\mathrm{S}$ contributed to the maximal degree to the obtaining of E, intended that E result for its own sake, and had maximally certain foresight that S's causal contribution would lead to the obtaining of E. (Such a condition might be satisfied by God's creation of the material world in its initial state ex nibilo, for instance.)
} 
differ from case $\mathrm{X}$ in some respect with regard to the initial conditions, since in case $\mathrm{X}$, the contribution of each teenager is causally necessary for moving the boulder, whereas in case $\mathrm{Y}, \mathrm{S}$ acts alone to accomplish (roughly) the same thing. Now compare case $\mathrm{Y}$ to a third case, $\mathrm{Z}$, which involves just two persons, $S$ and $P$. Suppose that $S$ casually suggests to $P$ the possibility that $P$ could push the boulder down the slope all by herself, without any (other) help from S; imagine that $S$ then walks away, but thanks to S's suggestion, $\mathrm{P}$ freely decides to do this and does so, where this possibility would not have occurred to $P$ without S's prompting.

Shouldn't we say that S's moral responsibility for the damage to the car in case $\mathrm{Z}$ is less than $\mathrm{S}$ 's moral responsibility for the damage to the car in case Y? After all, if we hold all of the other factors constant, S's causal contribution to the wrecking of the car in case $\mathrm{Z}$ is not causally sufficient (in the circumstances) for the wrecking of the car, since it must operate "through" P's free decision to push the boulder down the slope all by herself. (If P's decision is free, then it is not determined by the prior events, including S's attempts to persuade. ${ }^{16}$ ) By contrast, if we hold all of the other factors constant, S's causal contribution to the wrecking of the car in case $\mathrm{Y}$ is causally sufficient (in the circumstances) for the wrecking of the car. Doesn't this difference clearly indicate different degrees of causal contribution in the two cases, and doesn't this difference indicate a difference in degrees of moral responsibility in the two cases?

I think so. But Zimmerman offers an argument against this approach. He mentions a variant on his original case X which involves $S$ twisting P's arm so that $\mathrm{P}$ will help $S$ to push the boulder against P's will, and says this about such a case:

In a case such as that just given it is common and tempting to talk of the differing "extents" to which S and P contributed to the outcome; but I think that such talk should be avoided. Presumably more blame is to be ascribed to $\mathrm{S}$ than to $\mathrm{P}$ - he is more to blame for the outcome than $\mathrm{P}$ is, he is also to blame for twisting P's arm, and so on- but, given that the action of each is causally necessary and of neither is causally sufficient for the out-

\footnotetext{
${ }^{16}$ Here I am assuming, of course, that P's decision is free in some libertarian sense. (Those who find this example incoherent because they find the concept of libertarian freedom incoherent will find a different example of degrees of causal contribution leading to different degrees of responsibility in the discussion of Zimmerman in the next few paragraphs.) For persuasive arguments for the conclusion that intervening agents do not necessarily diminish moral responsibility, in general, see Zimmerman 1985b.
} 
come, it seems misleading to talk of $S$ contributing to a greater extent than $\mathrm{P}$ to this outcome. In general, it seems to me best to say the following. There is a sense to be attached to the claim that different individuals have more or less "important" roles in the production of an outcome, but such a claim is, first, a normative one and, second, not to be confused with the non-normative issue of contribution to an outcome (a factor which admits of no degrees). (Zimmerman 1985a, 117)

I think that Zimmerman is mistaken here: just because various factors are in themselves neither causally necessary nor causally sufficient for a given outcome, it does not follow that there can be no differences between them in terms of their respective causal contributions. Case Z, involving causal contribution that is non-necessitating, seems to illustrate this clearly; causal contribution is a matter of degree.

Here is another way to illustrate this same point, this time by reference to another hypothetical case from Zimmerman. This case involves group action which is sequential instead of simultaneous:

Imagine a dozen people, with murder on their minds, each delivering one stab to the body of some victim. Let us suppose that each of the stabs is causally necessary for the death to ensue. I submit that, given certain other conditions (full freedom, intent, and so forth), each of the assailants is fully morally responsible for the death. (Zimmerman 1985a, 117)

Zimmerman's argument for this last claim is essentially similar to the one mentioned earlier in connection with case $\mathrm{X}$ : each of the stabs is causally necessary but not causally sufficient, so each of the assailants is morally responsible to the same degree for the outcome. Furthermore, we could imagine a case in which only one of the assailants administered just one stab and killed the victim, and there is no reason to regard that one person's moral responsibility in the modified case as different from his moral responsibility in the original case involving the twelve people.

But Zimmerman's case of the dozen stabbers can be modified easily to illustrate different degrees of causal contribution. Suppose that instead of people stabbing, we have a million people, each laying a single straw on the proverbial camel's back, except for the last person, who lays a hundred 
straws on the camel's back (all at once, let's say). ${ }^{17}$ As before, let's follow Zimmerman in assuming that each of the million straws is causally necessary for the outcome. Isn't it obvious that the person who lays a hundred straws at once contributes causally to the breaking of the camel's back to a greater extent than any of the other people do? This gives us good reason to think that Zimmerman is mistaken here, that causal contribution does come in degrees, and that degrees of causal contribution help to determine degrees of moral responsibility.

However, Zimmerman offers one final argument in this connection that is worth considering. This argument occurs in the context of the evaluation of group action which is oversupplied:

If the argument concerning the possibility of the proper ascription of full moral responsibility to each of the participants in a standard simultaneous group action is successful, then it is easy to argue for this possibility when it is oversupplied rather than standard action that is at issue. Suppose that fifteen teenagers had pushed the boulder instead of ten. This surely would not have diminished the responsibility of any of the original ten. (What an easy "out" that would be! Just invite a few more friends to participate.) (Zimmerman 1985a, 119)

My claim about the relevance of causal contribution to moral responsibility might seem to imply that Zimmerman's case of oversupplied group action should be diagnosed as involving diminished moral responsibility for the participants. But this apparent implication is only apparent; I agree with Zimmerman's claim that adding more agents is insufficient, all by itself, to diminish moral responsibility. As Zimmerman says, in another context,

To say that someone is fully responsible is not to say that he is solely responsible; responsibility is not to be cut up, like a pie, so that the more people that join in a wrongdoing, the less responsibility to be allocated to each. (Zimmerman 1985b, 355)

But it is easy to imagine a case which is similar to Zimmerman's case involving the ten teenagers pushing the boulder in which it does make a

\footnotetext{
${ }^{17}$ For further discussion of this example with respect to the responsibility for created persons in connection with answered petitionary prayers, see Davison 2017, chapter 7.
} 
difference if more agents are added. For example, suppose that fifteen teenagers are involved instead of ten, and imagine that the causal contribution of each teenager is reduced accordingly (so that the case is not oversupplied, but rather standard, like the original case $\mathrm{X}$ ). Then it seems reasonable to say that the moral responsibility of a given participant $S$ would be less in this case than it would be in the original case $\mathrm{X}$, all other things being equal. The difference might be slight, of course, and perhaps not important enough to make a difference practically in terms of our response to each individual, but there would be a difference.

Hence I conclude that Zimmerman is mistaken about degrees of causal contribution and that different degrees of causal contribution explain different degrees of moral responsibility, at least in some cases. But notice that along the way, Zimmerman has shown that just because one agent is fully morally responsible for a given event, it does not follow that no other person can be morally responsible for that same event-in other words, the Augustinian premise 12 is false. ${ }^{18}$ How should traditional theists who wish to pursue something like an Augustinian approach to answering the problem of evil respond to this?

It seems to me that they should accept the claim that God is partly morally responsible for evil in the world, but then argue that God's responsibility does not imply that God is worthy of blame for such evil. This could be done by explaining the reasons that actually justify God's permission of evil (in the case of theodicy), or explaining the reasons that could justify God's permission of evil (in the case of defense), or simply explaining why we should not expect to know such reasons if they existed (in the case of the so-called skeptical theism). If these strategies are successful, then either God would be worthy of praise for God's contributions to such things, or at least God would be neither worthy of praise nor worthy of blame (although satisfying the other requirements for moral responsibility, in the sense mentioned at the beginning of this chapter). Whether or not such

\footnotetext{
${ }^{18}$ By way of reminder, I am understanding premise 12 of the Augustinian argument in terms of efficient causes. The argument I have cited here as showing that premise 12 of the Augustinian argument involves only creaturely efficient causes, rather than a combination of divine and efficient causes, but I don't see how that makes any difference. (If there are other kinds of causation, then perhaps some analogue of premise 12 is true for them; I am agnostic about this possibility.)
} 
strategies can be successful, in terms of explaining how God could be responsible but not blameworthy for evil, falls beyond the scope of this chapter. ${ }^{19}$

\subsection{CONCLUSION}

We should conclude that the ontological randomness involved in creaturely libertarian freedom (should actual creatures possess it, of course) does not by itself imply that God is not morally responsible to any degree for the free actions of creatures, whether good or evil, assuming (as traditional theists do) that God makes some causal contribution to the free actions of creatures. But what about random events that do not involve the free actions of any creatures, such as the random decay of radioactive isotopes?

In cases such as these, it seems important to note that the randomness in question is randomness over a limited range of possible outcomes. In the famous example of Schrödinger's cat, for instance, there are only two possible states of the radioactive substance in the box with the cat: either it has decayed, or it has not. If it has decayed, then the Geiger counter detects the decay and triggers the hammer to release the poison, which kills the cat. If it has not decayed, then the Geiger counter does not detect the decay and does not trigger the hammer to release the poison, so the cat remains alive. Whether or not the cat is dead, then, involves what I have called ontological randomness. But this arrangement does not involve the possibility of the cat becoming a full-grown horse, a nuclear weapon, or an atom of hydrogen; these last three outcomes are inconsistent with the initial arrangement.

So if God is morally responsible for the fact that a random process is in place that will result in either X or $\mathrm{Y}$, and God knows this, then it seems clear that God is morally responsible to some degree for $\mathrm{X}$ if it occurs and morally responsible to some degree for $\mathrm{Y}$ if it occurs. Assuming (as I have) that God's degree of causal contribution to the outcome of a random process is not sufficient to guarantee any particular outcome, we might think that God's causal contribution in such cases is less than it is in cases

\footnotetext{
${ }^{19}$ For an approach to theodicy that does not appeal to libertarian freedom among creatures at all, or to any kind of compensation in an afterlife, see my forthcoming paper, "A Naturalistic Intrinsic Value Theodicy."
} 
in which God's causal contribution is sufficient to guarantee a particular outcome. But as the discussion of degrees of causal contribution shows, causal contribution and hence moral responsibility come in degrees, so we cannot conclude that those cases that involve God's causal contribution to random processes are cases in which God's causal contribution is not necessary or important. Hence traditional theists need not reject Divine Moral Responsibility because of the existence of what I have called ontologically random events in the world. ${ }^{20}$

\section{BiBLIOGRAPHY}

Adams, Robert M. 1985. Involuntary Sins. The Philosophical Review XCIV (1): $3-31$.

Clarke, Randolph. 2003. Libertarian Accounts of Free Will. Oxford: Oxford University Press.

Davison, Scott A. 2012. On the Intrinsic Value of Everything. New York: Continuum Press.

- 2017. Petitionary Prayer: A Philosophical Investigation. Oxford: Oxford University Press.

- 2019. A Naturalistic Intrinsic Value Theodicy. In Oxford Studies in Philosophy of Religion, ed. Lara Buchak, Dean Zimmerman, and Philip Swenson, 236-258. Oxford: Oxford University Press.

de Molina, Luis. 1988. On Divine Foreknowledge (De liberi arbitri cum gratiae donis, divina praescientia, providentia, praedestinatione et reprobatione Concordia. Translated with an introduction by Alfred J. Freddoso. Ithaca: Cornell University Press.

- 1989. Liberi arbitri cum gratiae donis, divina praescientia, providentia, praedestinatione et reprobatione concordia, Disputations 32. Translated by Alfred J. Freddoso. https://www3.nd.edu/ afreddos/translat/ molina32.htm

Fischer, John Martin, and Mark S.J. Ravizza. 1998. Responsibility and Control: A Theory of Moral Responsibility. Cambridge: Cambridge University Press.

Frankfurt, Harry G. 1969. Alternative Possibilities and Moral Responsibility. Journal of Philosophy 66: 829-839.

\footnotetext{
${ }^{20}$ For a very different approach to a closely related question, see van Inwagen 1995 and the reply in Freddoso 1987. Many thanks to Jeff Koperski, Kelly James Clark, Thomas P. Flint, Samuel Lebens, Emil Salim, Marilee Coetsee, and other participants in the third annual Abrahamic Reflections on Science and Religion program in Casablanca, Morocco, for helpful comments and suggestions concerning earlier versions of this chapter.
} 
Freddoso, Alfred J. 1987. Comment on Peter van Inwagen's 'The Place of Chance in a World Sustained by God.' https://www3.nd.edu/ afreddos/papers/ chance.htm . 1988. Medieval Aristotelianism and the Case Against Secondary Causation in Nature. In Divine and Human Action: Essays in the Metaphysics of Theism, ed. Thomas V. Morris, 74-118. Ithaca: Cornell University Press.

Goldschmidt, Tyron. 2016. A Demonstration of the Causal Power of Absences. Dailectica 70 (1): 85.

Hick, John. 1966. Evil and the God of Love. New York: Harper \& Row.

Howard-Snyder, Daniel. 2008. The Puzzle of Prayers of Thanksgiving and Praise. In New Waves in Philosophy of Religion, ed. Yujin Nagasawa and Erik Wielenberg, 125-149. New York: Palgrave Macmillan.

Jordan, James. 1987. Western Philosophy: From Antiquity to the Middle Ages. New York: Macmillan Publishing Company.

Kane, Robert. 1985. Free Will and Values. Albany: State University of New York Press.

Mackie, John L. 1955. Evil and Omnipotence. Mind 64: 200-212.

- 1982. The Miracle of Theism. Oxford: Oxford University Press.

McCloskey, H.J. 1960. God and Evil. The Philosophical Quarterly 10: 97-114.

Morriston, Wes. 2000. What Is So Good About Moral Freedom? The Philosophical Quarterly 50 (200): 344-358.

Nagel, Thomas. 1976. Moral Luck. Proceedings of the Aristotelian Society 50 (Supplementary Volume): 137-151.

O'Connor, Timothy. 2000. Persons and Causes. New York: Oxford University Press. Plantinga, Alvin. 1974a. God, Freedom, and Evil. New York: Harper and Row.

- 1974b. The Nature of Necessity. Oxford: Clarendon Press.

Plantinga, Alvin, and Michael Tooley. 2008. Knowledge of God. Malden: Blackwell Publishing.

Plato. 1925. Timaeus. Translated by W.R.M. Lamb. In Plato in Twelve Volumes. Vol. 9. Cambridge, MA: Harvard University Press; London: William Heinemann Ltd.

St. Augustine. 1993. On Free Choice of the Will. Translated with an introduction by Thomas Williams. Indianapolis: Hackett Publishing Company.

Van Inwagen, Peter. 1983. An Essay on Free Will. Oxford: Oxford University Press.

- 1995. The Place of Chance in a World Sustained by God. In God, Knowledge, and Mystery, 42-65. Ithaca: Cornell University Press.

Zimmerman, Michael J. 1985a. Sharing Responsibility. American Philosophical Quarterly 22: 115-122.

Zimmerman, Michael F. 1985b. Intervening Agents and Moral Responsibility. The Philosophical Quarterly 35: 347-358. 
Open Access This chapter is licensed under the terms of the Creative Commons Attribution 4.0 International License (http://creativecommons.org/licenses/ by $/ 4.0 /$ ), which permits use, sharing, adaptation, distribution and reproduction in any medium or format, as long as you give appropriate credit to the original author(s) and the source, provide a link to the Creative Commons licence and indicate if changes were made.

The images or other third party material in this chapter are included in the chapter's Creative Commons licence, unless indicated otherwise in a credit line to the material. If material is not included in the chapter's Creative Commons licence and your intended use is not permitted by statutory regulation or exceeds the permitted use, you will need to obtain permission directly from the copyright holder. 